\title{
Occupational Stress effects and Job Performance in the Teachers of Schools of Punjab (Pakistan)
}

\author{
Kashif Ali \\ MS (Finance) from Riphah International University Islamabad \\ Irtaza Ishtiaq \\ MBA (3.5) from International Islamic University Islamabad \\ Muneeb Ahmad \\ MS (Finance) from Riphah International University Islamabad
}

DOI: $\quad 10.6007 /$ IJARBSS/v3-i11/400 URL: http://dx.doi.org/10.6007/IJARBSS/v3-i11/400

\begin{abstract}
:
This research scrutinizes the subject of work-related stress in the teachers of Pakistani private schools. Research confining data on work-related stress in individual schools fluctuate in requisites of their span, tactic and exposure. The major risk issues for work-related stress comprise heavy workload, long working hours, lack of control and autonomy at work, poor relationships with colleagues, poor support at work and the shock of managerial transform. These factors can be difficult to address, especially if they have reserve suggestion. The main product (individual, managerial and community) of work-related stress embrace physical and mind health harms, nonexistence from work, reduced quality of productivity, augmented happiness and medical payments, and abridged output. Company-level examples of best put into practice in stress organization emphasize the need for good excellence data on occupational stress, a robust stress policy, the participation of all pertinent actors, good infrastructure, and the significance of buy-in from senior administration.
\end{abstract}

Keywords: work-related stress, Male Female Teachers, Performance

\section{Introduction:}

The modern world is of competition and life is full of challenges. Any challenge that exceeds the coping abilities of the individual becomes stress. In spite of proliferation of health institution both in public and private sector, health problems are on increase and these are caused by stress and tensions. In general stress is perceived as negative condition but a certain level of stress is necessary for the effective function-ing. Stress cannot be ignored or avoided but can be managed.

According to Mason (1975), stress was approached in four different ways, Stimulus or external force acting on the organism, Response or changes in the physiological functions, External force and resistance opposed to it and Comprehensive phenomenon encompassing all these. The teachers serve one of the most stressful professions. Stress has been found to be costly to the individual as well as to the institution where he/she works (Cooper \& Marshal, 1978). Borg(1990), conceptualizes teacher stress as a negative and potentially harmful to teachers' health. The key element in the definition is the teacher's perception of threat based on the listed aspects of his job circum-stances i.e that the demands are being made on him, that he is unable to meet or has difficulty in meeting these demands and the failure to meet these demands threatens his mental/physical well being."

In relation to the profession of teaching, where a teacher is viewed as dispensers of knowledge; teachers are increasingly perceived as facilitators or managers of knowledge. They work in a constant socially isolated environments surrounded by hostile views and sometimes threat of physical abuse, and at the same time under a constant fear and threat of accountability for each and every action of both own self and that of the pupil. This alone can be a sufficient cause for stress for an individual. But in the case of a teacher it is multiplied by other factors as well Teaching has been identified as one of the most stressful professions today. The reasons 
for that are quite similar to other stressful occupations in the world. In a survey assessing the stress levels of variousjobs by the Health and Safety Executive, teaching came out top. The report, The Scale of Occupational Stress: further analysis of the impact of demographic factors and type of job, published in 2000, found that $41.5 \%$ of teachers reported themselves 'highly stressed', while $58.5 \%$ came into a 'low stress' category, while $36 \%$ of teachers felt the effects of stress all or most of the time.

This is indeed an alarming state and visibly also the biggest reason for school teachers quitting at a very high percentage or seeking professional help to fight back stress. Occupational stress has become increasingly common in teaching profession largely because of increased occupational complexities and increased economic pressure on individuals. A major source of distress among teachers is result of failure of school to meet the social needs and jobs demands of the teachers.

The teacher must be aware of his clear role to build up the nation. Teachers are over burdened with regular teaching load. Occupational satisfaction is a necessary condition for a healthy growth of teacher's personality. A teacher at present has a vulnerable position. College teachers protest that they are not paid enough. The importance of pay or a factor in occupational has been greatly over emphasized. In general, occupational stress arises from the working conditions/environment of a system, when we talk of stress among teachers. Many factors cause stress among teachers. School teachers face high amounts of stress during teaching and handling students; Classroom in developing countries remain overcrowded and teacher face intensive verbal communications, prolonged standing, high volume of work load.

Teachers are also over burdened with regular teaching work and non-teaching work as election duties, duty in census; populations counting etc. the teachers are often heard of complaining about. Teaching profession occupies important and prestigious place in society. Teachers are considered as the creators of leaders, scientists, philosophers, advocates, politicians and administrators. Teacher is the principle means for implementing all educational programmers of the organizations of educations. With the changing socio-economic scenario and increasing unemployment, the values of teacher and their professional concerns associated with the job have undergone a change, increasing stresses and hassles of teachers.

\section{Literature Review:}

It is concluded that teachers highly satisfied with their jobs (13.5\%) or who were highly stressed on their jobs were few (2.5\%). Most of the teachers were however averagely satisfied on each variable used in questionnaire to assess the level of job stress and job satisfaction

(Manzoor, 2011)

The university's faculty in Pakistan is experiencing a moderate level of stress as majority's response (67\%) reported stress as not a big problem The further classification of respondents into male and female faculty also supports the findings of pervious table showing moderate level of stress as male (70\%) and female (63\%) do not take stress as a big problem. Very few respondents of both genders have reported that stress is real problem for them (Chaudhry, 2012).

The Pearson correlation is applied to test significance of relationship between job satisfaction and overall occupational stress of faculty members of universities. According to the table statistics, there is no significant relationship found between job satisfaction and overall occupational stress. The results lead to the no rejection of Ho1. The further analysis of relationship across the various demographical variables may reveal statistically significant relationship between related items (Abdul Qayyum Chaudhry, 2012).

Out of six variables of Occupational Role Questionnaire used in the study according to Occupational Stress Inventory, three variables show significant differences. In terms of role insufficiency and role ambiguity, less experienced teachers are having comparatively more stress than experienced teachers. In role overload, responsibility physical environment, and role boundary both of them report average and almost equal stress. Gender wise analysis also reveals that male and female teachers of the selected school are exposed to average and normal stress (RNI-RAJBIL, 2009).

At the school, the increase in stress is reflected in growing annual average of days of teacher absences and rise in the number of early retirements. (Clark, 1985). As the modern India is passing through an intricate state, at such times it is the teachers only who can make the 
student realize that the burden of country lies on the shoulder of youth. While going into the depth of these professionals, we find that level as (Lath, 2012).

The results of the study indicates that the nature of colleagues effect the occupational stress among teachers. The has tie to finish the work, failure to perform duty smoothly, unclear instructions and insufficient facilities, unclear expectations of higher authority, cooperation in doing other's work and the assignment of having workload and lack of time are the significant factors included by the component 1 , which are responsible for maintaining occupational stress and job dissatisfaction among the teachers. Monotonous nature of assignment, ignorance of higher authority and violation of administrative processes and policies are significant factors included by principle component two, causing occupational stress among the teachers (Singh, 2009).

The results indicated that, if the organizational communication variables were not in the regression models, occupational stress, especially school domain and student domain stress, could predict substantial variance in job satisfaction. The results confirm earlier studies that established negative associations between job satisfaction and occupational stress. Of import are the associations between stress arising from lack of support from university administration, and general job satisfaction, and particularly the strong association between this stressor and job satisfaction from supervision, job variety, staff-principal relationship and staff-student relationships (Nizami, 2012).

Work stress is a real challenge for college teachers and their employing institution. As institution and their working environment transform, so do the kinds of stress problems that teachers may face. It is important that your workplace is being continuously monitored for stress problems. So, in this paper, we have discussed about various occupational stresses among engineering colleges in Punjab, India (Gabha, 2013).

Female primary school teachers were found to have more stress as compared to male primary school teachers of District Budgam. The main reason is that females feel insecurity in terms of safety, job, pressure from home and society. (ii) Private male primary school teachers were found to have more stress as compared to Govt. male primary school teachers of District Budgam. The main reason is that private males feel insecurity in terms of safety, job, pressure from home and society (Jan, 2013).

Stress related with job or occupation is called occupational stress. Occupational stress refers to a situation where occupation related factors interact with employee to change, disrupts or enhance his psychological and physiological conditions such that the person is forced to deviate from normal functioning. (Pabla, 2012)

Stress is considered as an involuntary response to a dangerous situation. When we face a situation which our brain is incapable of handling, it puts the body on alert by producing hormones which are required in fight or flight situation, which are: Increased blood pressure, rapid heartbeat, reduced blood supply to the skin, cessation of digestive activities, increase perspiration, Additional release of sugar and fast into the system to coup up with the additional energy requirement, decrease in immune system's functions to preserve it for later action (Kaur, 2011).

The study also found significant insights in the average stress scores of faculty members in these schools with respect to various background variables. It is found that average stress scores of the faculty members in the Business Schools have significant differences due to their designation, as high stress is associated with lower designations, i.e. Lecturer, Assistant Professors. So stress \& designation moves in opposite direction; higher the designation, lower will be the stress (Akbar, 2011).

The male and female elementary school teachers do not differ significantly on sub-scales: Role overload, Responsibility for persons, strenuous working conditions and Unprofitability. The male and female elementary school teachers differ significantly on overall occupational stress level. Female elementary school teachers have more stress level them male elementary school teachers (Kumar, 2013).

The analysis of this findings resulted in categorizing them into three groups: personal stress, professional stress and financial stress. However, the impact of each one of the three groups of teacher stress (i.e. personal, professional and financial) was different for different teachers. It looked like some teachers felt more stressed because of a variety of personal and domestic factors, whereas other teachers felt more constrained because of financial issues. Furthermore, the data analysis also highlighted the sources of teacher stress, which could be easily identified 
as the "inside-school" and the "outside-school" sources of stress. The various findings related to each one of the two categories are revealing as they show the significance and degree of enormity of stress factors related to these groups. (Sultana, 2012)

An understanding of both the nature of stress and the sources of stress facing school administrators and senior teachers can provide useful basis for developing appropriate strategies which can be applied to reduce stress. Spending more time with family, regular exercise, Meditation and Good diet, all contribute to reduce level of stress. School systems should therefore promote an awareness of health knowledge in their schools regarding administrators and senior teachers stress in the areas of administration, school climate, and resources through communication and training (Hashim).

Student academic improvement is a worthy goal, but it is not achieved in isolation. Teachers' attitudes and performance are critical to that endeavor. Learning to cope with stress successfully has multiple benefits for teachers, and the suggestions in this study offer some valuable options that may improve a teacher's sense of well-being. Concern for the effects of unrelenting stress in the lives of our teachers cannot be minimized or ignored. Policymakers and educators must realize that good teachers can succumb to burnout and work actively to demonstrate that concern. It is true that "children are our future," but teachers lead the way. For the good of our students as well as our society, the subject of teacher stress deserves our attention and our support (Richards, 2012).

Stress of varying degrees is an inevitable phenomenon in teaching and possibly in all other careers of life. Ling (1991), Yahaya et al. (2008) and Devonport et al. (2008) note that teaching in its nature is highly stressful. If teachers' stress is not minimized or unresolved, it will directly or indirectly have ripple effects on the teachers' emotional, mental and physical health which may have negative effects their effectiveness in teaching and learning process. Obviously, when teachers are unduly stressed, education system will be impaired, thus inefficiency may ensue (Agbatogun, 2010).

Findings of the present study indicate that teachers experience high levels of stress manifestations. Teachers who become closely involved and preoccupied with the personal and family problems of their learners may increase their vulnerability to burnout and depression (Brownell, 1997).Therefore support groups could be established at schools to assist teachers struggling with depression. Teachers should also be trained in stress reduction programmers, stress factors among teachers in schools of industry (Putter, 2003).

Analysis of data reflected that the numerous factors related to teachers stress could fall under the "personal" and "professional" aspects of teachers' lives. Likewise, we found a variety of sources of teachers stress factors: they emanated from the unfriendly working conditions in schools, from inadequate salary packages and lack of resources in schools (Ramzan, 2012).

\section{Methodology:}

Dependent variable is employee performance, job stress has been taken as independent variable while Work overload \& time pressure, lack of administrative support, coworker's relationship, family \& work life balance, problematic customer relations, riskiness of job and excessive work demand have been taken as moderating variables. The most important rationale of the study is to find out the factors caucuses' job stress and the correlation among job stress and employee performance. To achieve the objectives of the study 135 surveys were sent (through questioners) to 6 larger Schools having branches in allover Punjab. All the workers were matured among 20 to 60 years. Therefore 135 questionnaires were returned having reply rate of $94.8 \%$. The questionnaire using 5-Scale Liker (1=Highly Agreed 2=Agreed, 3=somehow Agreed, 4=Disagreed, 5=Highly Disagreed) was planned to check the impact of all the variables. For this study the questionnaire is divided into 2 sections demographics and job stress \& its impact on employee concert. The questionnaire coat all the variables such as lack of administrative support, excessive work demand, problematic customer relations, coworker's relationship, family \& work life balance and riskiness of job. The data was analyzed through SPSS v.19.

\section{Sample Characteristics:}

The Tables below summarize the respondents' characteristics according to their gender, age, qualification, working positions, experience and income. Male teachers made the healthy proportion of the sample size. About $66.40 \%$ of the respondents were under 30 years 
of age. $57.30 \%$ of respondents having Master's degree, which has income range from 41 to 60 thousands rupees.

Table I: Respondent's gender.

\begin{tabular}{|l|l|l|l|}
\hline & Frequency & Percent & Cumulative Percent \\
\hline & & & \\
Male & 90 & 66.40 & 66.40 \\
Female & 45 & 33.60 & 100 \\
\hline & 135 & 100 & \\
\hline
\end{tabular}

Table II: Respondent's Age.

\begin{tabular}{|c|l|l|l|}
\hline & Frequency & Percent & Cumulative Percent \\
\hline Less than 30 yrs & 65 & 50.78 & 57.78 \\
31 to 40 yrs & 35 & 27.34 & 77.78 \\
41 to 50 yrs & 23 & 15.63 & 93.41 \\
More than 51 yrs & 12 & 6.25 & 100 \\
\hline & 135 & & \\
\hline
\end{tabular}

Table III: Respondent's marital status.

\begin{tabular}{|l|l|l|l|}
\hline & Frequency & Percent & Cumulative Percent \\
\hline & & & \\
Married & 82 & 58.59 & 58.59 \\
Single & 53 & 41.41 & 100 \\
\hline & 135 & 100 & \\
\hline
\end{tabular}

Table IV: Respondent's qualification.

\begin{tabular}{|l|l|l|l|}
\hline & Frequency & Percent & Cumulative Percent \\
\hline Graduation & 52 & 35.15 & \\
Masters & 79 & 57.03 & 35.15 \\
MS/M.phil & 9 & 7.81 & 92.18 \\
PhD & 2 & 0 & 100.0 \\
\hline & 135 & 100 & \\
\hline
\end{tabular}


Table V: Respondent's nature of the job contract.

\begin{tabular}{|l|l|l|l|}
\hline & Frequency & Percent & Cumulative Percent \\
\hline & & & \\
Permanent & 95 & 69.53 & 69.53 \\
Temporary & 40 & 30.47 & 100 \\
\hline & 135 & 100 & \\
\hline
\end{tabular}

Table VI: Respondent's working position.

\begin{tabular}{|l|l|l|l|}
\hline & Frequency & Percent & Cumulative Percent \\
\hline & & & \\
Officer & 47 & 35.16 & 35.16 \\
Supervisor & 41 & 32.81 & 67.97 \\
Assistant manager & 28 & 19.53 & 87.5 \\
Manager & 19 & 12.5 & 100 \\
\hline & 135 & 100 & \\
\hline
\end{tabular}

Table VII: Respondent's income range.

\begin{tabular}{|l|l|l|l|}
\hline & Frequency & Percent & Cumulative Percent \\
\hline Less than 20,000 & 31 & 22.66 & 22.66 \\
21,000 to 40,000 & 35 & 25.00 & 47.66 \\
41,000 to 60,000 & 41 & 32.03 & 79.69 \\
More than 60,000 & 28 & 20.31 & 100 \\
\hline & 135 & 100 & \\
\hline
\end{tabular}

Table VIII: Respondent's Area of Responsibilities.

\begin{tabular}{|l|l|l|l|}
\hline & Frequency & Percent & Cumulative Percent \\
\hline Customer services & 24 & & \\
Administration & 35 & 18.75 & 18.75 \\
Sales \& Distribution & 23 & 25.78 & 44.53 \\
Planning \& & 19 & 18.75 & 63.28 \\
Implementation & 15 & 12.50 & 75.78 \\
Finance department & 12 & 10.94 & 86.72 \\
Trade Marketing & 7 & 8.59 & 95.31 \\
Others & & 4.69 & 100 \\
\hline
\end{tabular}


Table IX: Respondent's working experience in the organization.

\begin{tabular}{|c|l|l|l|}
\hline & Frequency & Percent & Cumulative Percent \\
\hline & & & \\
Less than 5 yrs & 30 & 19.53 & 19.53 \\
5 to 10 yrs & 57 & 42.97 & 62.50 \\
11 to 15 yrs & 35 & 27.34 & 89.84 \\
More than 15 yrs & 13 & 10.16 & 100 \\
\hline & 135 & 100 & \\
\hline
\end{tabular}

GENERAL FINDINGS:

Does your educational qualification suits your job?

\begin{tabular}{|l|l|l|l|l|}
\hline & Frequency & Percent & Valid Percent & Cumulative \\
& & & & Percent \\
\hline Valid & 57 & 42.97 & 42.97 & 42.97 \\
Agree & 44 & 32.81 & 32.81 & 75.28 \\
\multicolumn{1}{|c|}{ Some } & 15 & 11.72 & 11.72 & 87.00 \\
How & 7 & 8.59 & 8.59 & 95.59 \\
Disagree & 135 & 3.91 & 3.91 & 100 \\
S.Disagree & & 100 & 100 & \\
Total & & & & \\
\end{tabular}

The above table shows that $42.97 \%$ Strongly agreed, $32.81 \%$ agreed, 11.72 somehow agreed that their qualification suits with their job. Only $8.59 \%$ disagreed, $3.91 \%$ strongly disagreed and said that their educational qualification does not suit with their job which cause stress to them.

Lack of administrative support:

\begin{tabular}{|l|l|l|l|l|}
\hline & Frequency & Percent & Valid Percent & Cumulative \\
& & & & Percent \\
\hline S.Agree & 28 & 19.53 & 19.53 & 19.53 \\
Agree & 43 & 32.81 & 32.81 & 52.34 \\
\multicolumn{1}{|c|}{ Some } & 18 & 25.78 & 25.78 & 78.12 \\
How & 13 & 13.28 & 13.28 & 91.40 \\
Disagree & 135 & 8.59 & 8.59 & 100 \\
S.Disagree & & 100 & 100 & \\
\hline
\end{tabular}


Total

From the above table it is clear that lack of administrative support causes stress and the performance of the respondent decreases as the $19.53 \%$ respondent were strongly agreed, $32.81 \%$ were agreed and $25.78 \%$ were somehow agreed that lack of administrative support cause stress which in turns decrease their performance. $13.28 \%$ were disagreed and only $8.59 \%$ were strongly disagreed with that.

Work overload and time pressure:

\begin{tabular}{|l|l|l|l|l|}
\hline & Frequency & Percent & Valid Percent & Cumulative \\
& & & & Percent \\
\hline Valid & 29 & 21.09 & 21.09 & 21.09 \\
Agree & 45 & 35.94 & 35.94 & 57.03 \\
\multicolumn{1}{|c|}{ Some } & 19 & 17.97 & 17.97 & 75.00 \\
How & 13 & 14.84 & 14.84 & 89.84 \\
Disagree & 135 & 9.37 & 9.37 & 100 \\
S.Disagree & & 100 & 100 & \\
Total & & & & \\
\end{tabular}

The results are clearly indicating that significant majority of respondent were agreed(21.09\% were strongly agreed, $35.94 \%$ were agreed and $17.97 \%$ were somehow agreed) that work overload and time pressure is a big source of stress in their job and also leads towards decreased performance. While $14.94 \%$ were disagreed and $9.37 \%$ strongly disagreed.

\section{Problematic Customer relations:}

\begin{tabular}{|l|l|l|l|l|}
\hline & Frequency & Percent & Valid Percent & Cumulative \\
& & & & Percent \\
\hline S.Agree & 37 & 27.34 & 27.34 & 27.34 \\
Agree & 25 & 21.87 & 21.87 & 49.21 \\
How Some & 19 & 28.91 & 28.91 & 78.12 \\
Disagree & 11 & 14.06 & 14.06 & 92.18 \\
S.Disagree & 135 & 7.81 & 7.81 & 100 \\
\hline
\end{tabular}


Due to operational risk a banker often face problematic customer relations which cause stress. $27.34 \%$ were strongly agreed, $21.87 \%$ were agreed and $28.91 \%$ were somehow agreed that problematic customer relations caused stress and the performance of the respondent decreased. $14.06 \%$ were disagreeing and only $7.81 \%$ strongly disagreed with that.

\section{Coworkers Relation:}

\begin{tabular}{|l|l|l|l|l|}
\hline & Frequency & Percent & Valid Percent & Cumulative \\
& & & & Percent \\
\hline Valid & 55 & 45.31 & 45.31 & 45.31 \\
Agree & 35 & 28.13 & 28.13 & 73.44 \\
\multicolumn{1}{|c|}{ Some } & 12 & 14.85 & 14.85 & 88.29 \\
How & 5 & 8.59 & 8.59 & 96.88 \\
Disagree & 135 & 3.13 & 3.13 & 100 \\
S.Disagree & & 100 & 100 & \\
Total & & & & \\
\hline
\end{tabular}

The above table clearly demonstrates that coworker's relations caused stress to teachers working in bank.45.31\% respondent were strongly agreed, $28.1 \%$ agreed and $14.85 \%$ were somehow agreed that the lack of social support from colleagues and poor interpersonal relations cause stress and they feel inconvenient to work with them and hence their performance decreased. Only 3.13\% were disagreed with it.

\section{Riskiness of job:}

\begin{tabular}{|l|l|l|l|l|}
\hline & Frequency & Percent & Valid Percent & Cumulative \\
& & & & Percent \\
Valid & 32 & 25.78 & 25.78 & 25.78 \\
Agree & 30 & 21.09 & 21.09 & 46.87 \\
How Some & 32 & 30.47 & 30.47 & 77.34 \\
Disagree & 11 & 14.84 & 14.84 & 92.18 \\
S.Disagree & 135 & 7.81 & 7.81 & 100 \\
\hline Total & & 100 & 100 & \\
\hline
\end{tabular}

As in bank there is operational risk is involved while teachers are working. Due to online system of transactions teachers have to be careful while entering account details especially the amount of the transaction. Because once the data entered the transaction becomes online countrywide, thus any negligent act leads towards penalty to teachers. So this operational risk 
becomes a constituent of stress in teachers working in bank as in above table majority of the respondents agreed that riskiness of the job cause stress and ultimately decrease their performance.

Family and work life Relation:

\begin{tabular}{|l|l|l|l|l|}
\hline & Frequency & Percent & Valid Percent & $\begin{array}{l}\text { Cumulative } \\
\text { Percent }\end{array}$ \\
\hline Valid & 25 & 17.97 & 17.97 & 17.97 \\
S.Agree & 35 & 27.34 & 27.34 & 45.31 \\
Agree & 46 & 36.72 & 36.72 & 82.03 \\
\multicolumn{1}{|c|}{ Some } & 14 & 12.50 & 12.50 & 94.53 \\
How & 8 & 5.47 & 5.47 & 100 \\
Disagree & 135 & 100 & 100 & \\
S.Disagree & & & & \\
Total & & & & \\
\hline
\end{tabular}

Due to work over load the bankers have to spend extra time apart from their working hours so they are unable to manage work and family life properly that causes stress in them as the significant majority of respondents were agreed with that $(17.97 \%$ were strongly agreed, $27.34 \%$ were agreed and $36.72 \%$ were somehow agreed). $12.5 \%$ respondents were disagreed and $5.47 \%$ were strongly disagreed with that.

\section{Overall job stress:}

\begin{tabular}{|c|c|c|c|c|}
\hline & Frequency & Percent & Valid Percent & $\begin{array}{l}\text { Cumulative } \\
\text { Percent }\end{array}$ \\
\hline $\begin{array}{l}\text { Valid } \\
\text { S.Agree }\end{array}$ & $\begin{array}{l}55 \\
44\end{array}$ & $\begin{array}{l}40.62 \\
33.59\end{array}$ & $\begin{array}{l}40.62 \\
33.59\end{array}$ & $\begin{array}{l}40.62 \\
74.21\end{array}$ \\
\hline $\begin{array}{l}\text { Agree } \\
\quad \text { Some }\end{array}$ & $\begin{array}{l}19 \\
10\end{array}$ & $\begin{array}{l}13.81 \\
7.03\end{array}$ & $\begin{array}{l}13.81 \\
7.03\end{array}$ & $\begin{array}{l}88.02 \\
95.05\end{array}$ \\
\hline $\begin{array}{l}\text { How } \\
\text { Disagree }\end{array}$ & $\begin{array}{l}7 \\
135\end{array}$ & $\begin{array}{l}5.47 \\
100\end{array}$ & $\begin{array}{l}5.47 \\
100\end{array}$ & 100 \\
\hline $\begin{array}{l}\text { S.Disagree } \\
\text { Total }\end{array}$ & & & & \\
\hline
\end{tabular}

The above table demonstrates that $40.62 \%$ respondents were strongly agreed that their job is stressful, $33.59 \%$ were agreed and $13.81 \%$ were somehow agreed with that. Only $7.03 \%$ were disagreed and $5.47 \%$ were strongly disagreed and said their job is not stressful. 
What you Feel while you are on your job? (Tick one):

\begin{tabular}{|c|c|l|l|l|}
\hline & Frequency & Percent & $\begin{array}{l}\text { Valid } \\
\text { Percent }\end{array}$ & $\begin{array}{l}\text { Cumulative } \\
\text { Percent }\end{array}$ \\
\hline Aggressive and depressed & 27 & 23.44 & 23.44 & 23.44 \\
\hline Lazy boredom and headache & 19 & 14.06 & 14.06 & 37.50 \\
\hline Deficiency in work & 22 & 17.97 & 17.97 & 55.47 \\
\hline You do the best possible job & 13 & 9.38 & 9.38 & 64.85 \\
\hline Motivated, productive and creative. & 17 & 12.50 & 12.50 & 77.35 \\
\hline Better handle the situation & 9 & 7.03 & 7.03 & 84.38 \\
\hline Enjoy work & 13 & 10.16 & 10.16 & 94.54 \\
\hline Stay calm & 8 & 5.47 & 5.47 & 100 \\
\hline Total & 135 & 100 & 100 & \\
\hline
\end{tabular}

The above table shows what the respondents feeling while they were on their job. The data indicated that $23.44 \%$ of the respondents feel depression and become aggressive.14.1\% become lazy and suffered from headache. The $17.97 \%$ of the respondents did feel deficiency in work. So an enormous majority did feel stress and their performance decreased. Only $9.38 \%$ respondents do their best possible under stress. $12.50 \%$ become motivated and more productive in stressed environment. It was further envisaged from data that $7.03 \%$ respondents better handle the situation under stress,10.16\% Enjoy work and $7 \%$ respondents Stay calm and said that they never felt stress. The table of correlation analysis shows the relationships of all the variables. 


\section{Correlation analysis}

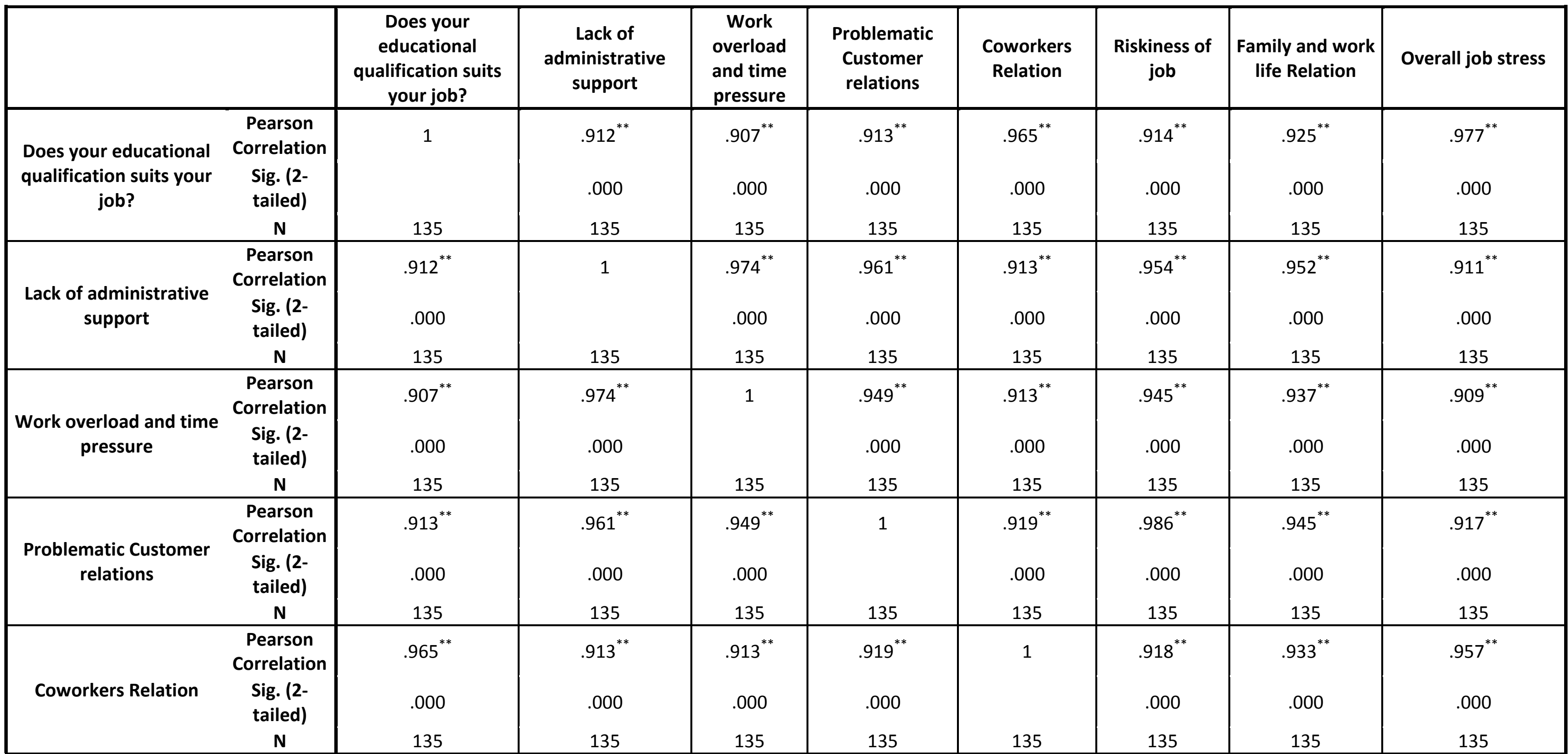




\begin{tabular}{|c|c|c|c|c|c|c|c|c|c|}
\hline Riskiness of job & $\begin{array}{c}\text { Pearson } \\
\text { Correlation } \\
\text { Sig. (2- } \\
\text { tailed) } \\
\mathbf{N}\end{array}$ & $\begin{array}{l}.914^{* *} \\
.000 \\
135\end{array}$ & $\begin{array}{l}.954^{* *} \\
.000 \\
135\end{array}$ & $\begin{array}{l}.945^{* *} \\
.000 \\
135\end{array}$ & $\begin{array}{l}.986^{* *} \\
.000 \\
135\end{array}$ & $\begin{array}{l}.918^{* *} \\
.000 \\
135\end{array}$ & $\begin{array}{c}1 \\
135\end{array}$ & $\begin{array}{l}.954^{* *} \\
.000 \\
135\end{array}$ & $\begin{array}{l}.917^{* *} \\
.000 \\
135\end{array}$ \\
\hline $\begin{array}{l}\text { Family and work life } \\
\text { Relation }\end{array}$ & $\begin{array}{c}\text { Pearson } \\
\text { Correlation } \\
\text { Sig. (2- } \\
\text { tailed) } \\
\mathbf{N}\end{array}$ & $\begin{array}{l}.925^{* *} \\
.000 \\
135\end{array}$ & $\begin{array}{l}.952^{* *} \\
.000 \\
135\end{array}$ & $\begin{array}{l}.937^{* *} \\
.000 \\
135\end{array}$ & $\begin{array}{l}.945^{* *} \\
.000 \\
135\end{array}$ & $\begin{array}{l}.933^{* *} \\
.000 \\
135\end{array}$ & $\begin{array}{l}.954^{* *} \\
.000 \\
135\end{array}$ & 135 & $\begin{array}{l}.932^{* *} \\
.000 \\
135\end{array}$ \\
\hline Overall job stress & $\begin{array}{c}\text { Pearson } \\
\text { Correlation } \\
\text { Sig. (2- } \\
\text { tailed) } \\
\text { N }\end{array}$ & $\begin{array}{l}.977^{* *} \\
.000 \\
135\end{array}$ & $\begin{array}{l}.911^{* *} \\
.000 \\
135\end{array}$ & $\begin{array}{l}.909^{* *} \\
.000 \\
135\end{array}$ & $\begin{array}{l}.917^{* *} \\
.000 \\
135\end{array}$ & $\begin{array}{l}.957^{* *} \\
.000 \\
135\end{array}$ & $\begin{array}{l}.917^{* *} \\
.000 \\
135\end{array}$ & $\begin{array}{l}.932^{* *} \\
.000 \\
135\end{array}$ & 135 \\
\hline
\end{tabular}

${ }^{* *}$ Correlation level is significant at 0.01 (2-tailed) 
The above table confirms that all job stress attributes (educational background, lack of administrative support, work overload and time pressure, riskiness of job, problematic customer relations, co-worker relations and family \& work life relations) are positively associated with overall job stress. Teachers education shows the highest positive correlation $(r=.977)$ with job stress and Co-worker relations the second highly positive correlation ( $r=$.957) with job stress, followed by riskiness of job $(r=.917)$, lack of administrative support $(r=.911)$, problematic customer relations $(r=.917)$, family and work life relations $(r=.932)$ all have positive association with job stress. Work overload and time pressure reveals the least but positive correlation $(r=.909)$ with job stress.

Regression:

\section{Model Summary}

\begin{tabular}{|l|r|r|r|r|}
\hline Model & $\mathrm{R}$ & R Square & Adjusted R Square & \multicolumn{2}{|c|}{$\begin{array}{c}\text { Std. Error of the } \\
\text { Estimate }\end{array}$} \\
\hline 1 & $.980^{\mathrm{a}}$ & .961 & .960 & .229 \\
\hline
\end{tabular}

The value of $R$ in the table is .980 , and $R$ square is .961 . The value of $R$ shows significantly positive relationship between variables (educational background, lack of administrative support, work Ooverload, riskiness of job, problematic customer relations, co-worker relations, family and work life relations) and overall job stress. The value of $\mathrm{R}$ square shows that model 1 explains $96 \%$ variance in overall job stress.

\section{Conclusion:}

Greater part of the teachers of schools of Punjab felt that their job is stress full and that stress in return reduces their performance. Work overload, risky job and poor co-worker relations were the major donor to job stress. Due to work overload and time pressure the teachers of schools in Punjab are not capable to handle work life with family life which cause some serious social problems. Therefore the overstressed job decreases teachers performance and perhaps a chief contributor to a teacher dissatisfaction. All these factors create a lot of problems for the teachers and they indulged into mental depression, smoking, heart disease, brain tumor and many other problems. To fulfill their job requirements workers use unfair means such as telling a lie, work shirking, fraud and lame excuses. Proper strategies should be made regarding working hours, interpersonal relationships and supervision of schools of Punjab to reduce stress and to better manage the performance of teachers. 


\section{References:}

1. Abdul Qayyum Chaudhry. (2012). The Relationship between Occupational Stress and Job Satisfaction:The Case of Pakistani Universities. International Education Studies , 217.

2. Agbatogun, A. O. (2010). Teachers' Management of Stress Using Information and Electronic Technologies. 6.

3. Akbar, A. (2011). Faculty Stress at Higher Education: A Study on the Business Schools of Pakistan . World Academy of Science, Engineering and Technology , 1082.

4. Chaudhry, A. Q. (2012). An Analysis of Relationship between Occupational Stress and . Bulletin of Education and Research, 13.

5. Darmody, M. (n.d.). A Report Compiled by the ESRI on Behalf of The Teaching Council. 11.

6. Gabha, D. V. (2013). Occupational Stress Among the Engineering College Teachers in Punjab, India. International Journal of Engineering Research and Technology , 88.

7. Hashim, C. N. (n.d.). Stress Management Among Administrators and senior Teachers of Private Islamic School. 5.

8. Jan, D. T. (2013). A STUDY OF SOCIAL AND FAMILY ROLE STRESS AMONG PRIMARY SCHOOL TEACHERS OF DISTRICT BUDGAM, J\&K, INDIA. Journal of Educational Research and Essays , 3.

9. Kaur, S. (2011). Comparative Study of Occupational Stress among Teachers of Private and Govt. Schools in Relation to their Age, Gender and Teaching Experience. International Journal of Educational Planning \& Administration. , 158.

10. Kumar, I. A. (2013). Occupational Stress among Male and Female Elementary School Teachers of District Pulwama. International Journal of Scientific \& Engineering Research , 940.

11. Lath, S. K. (2012). Perception of Occupational Stress among teaching professionals.

12. Majeed, S. S. (n.d.). Leading Stress Factors among School Teachers(An empirical Study of Pakistani school teachers). 15,16.

13. Manzoor, M. U. (2011). Global Journal of Management and Business Research , 5.

14. Nizami, K. (2012). The Investigation Of The Relation Between Job Stress And Job Satisfaction (Case. Advances in Natural and Applied Sciences , 228.

15. Pabla, D. M. (2012). Occupational Stress Amongst Teachers of Professional Colleges in Punjab. INDIAN JOURNAL OF RESEARCH , 112.

16. Putter, L. (2003). 52.

17. Ramzan, M. (2012). A Study on Understanding the Factors Contributing To Teachers' Professional Stress in the Private Schools of Gilgit-Baltistan. Strength for Today and Bright Hope for Tomorrow , 349.

18. Richards, J. (2012). Teacher Stress and Coping Strategies: A National Snapshot. http://www.tandfonline.com/loi/utef20, 312.

19. Singh, M. (2009). FACTORS CAUSING OCCUPATIONAL STRESS AMONG SENIOR SECONDARY SCHOOL TEACHERS OF AMRITSAR DISTRICT. Journal of Physical Education an Sport . 
20. Sultana, B. (2012). The Nature and Impact of Teacher Stress in the Private Schools of Gilgit-Baltistan, Pakistan. International Journal of Academic Research in Progressive Education and Development , 82,83. 